\title{
Correction: Integrated care programmes for sport and work participation, performance of physical activities and quality of life among orthopaedic surgery patients: a systematic review with meta-analysis
}

Coenen P, Hulsegge G, Daams JG, et al. Integrated care programmes for sport and work participation, performance of physical activities and quality of life among orthopaedic surgery patients: a systematic review with meta-analysis. BMJ Open Sport \& Exercise Medicine 2020;6: e000664. doi: 10.1136/bmjsem-2019-000664.

This article has been corrected since it was published online. The funding statement has been updated to: The study has partly been funded by the Amsterdam Public Health Research Institute as well as by The Netherlands Organisation for Health Research and Development, ZonMW (grant number 852001929).

(c) Author(s) (or their employer(s)) 2020. Re-use permitted under CC BY-NC. No commercial re-use. See rights and permissions. Published by BMJ.

This is an open access article distributed in accordance with the Creative Commons Attribution Non Commercial (CC BY-NC 4.0) license, which permits others to distribute, remix, adapt, build upon this work non-commercially, and license their derivative works on different terms, provided the original work is properly cited, appropriate credit is given, any changes made indicated, and the use is non-commercial. See: http://creativecommons.org/licenses/by-nc/4.0/.

BMJ Open Sp Ex Med 2020;6:e000664corr1. doi:10.1136/bmjsem-2019-000664corr1

D) Check for updates 